Journal of Contemporary Accounting

\title{
Fraud risk and trust on the intention to buy of e-commerce
}

\author{
Dewi Anggun Puspitarini \\ Department of Accounting, Universitas Catur Insan Cendekia, Cirebon, Indonesia \\ dewi.puspita@cic.ac.id \\ Prawira Aros Purnama \\ Department of Management, Universitas Catur Insan Cendekia, Cirebon, Indonesia \\ prawirapurnama91@gmail.com \\ Isti Riana Dewi \\ Department of Management, Universitas Catur Insan Cendekia, Cirebon, Indonesia \\ isti.riana@cic.ac.id
}

Follow this and additional works at: https://journal.uii.ac.id/jca

Copyright (C2021 Journal of Contemporary Accounting and Authors.

Dewi Anggun Puspitarini, Prawira Aros Purnama, \& Isti Riana Dewi. (2021). Fraud risk and trust on the intention to buy of e-commerce. Journal of Contemporary Accounting, 3(1), 45-52 doi:10.20885/jca.vol3.iss1.art5 


\title{
Fraud risk and trust on the intention to buy of e-commerce
}

\author{
Dewi Anggun Puspitarini ${ }^{1}$, Prawira Aros Purnama ${ }^{2}$, Isti Riana Dewi ${ }^{3}$ \\ ${ }^{1}$ Department of Accounting, Universitas Catur Insan Cendekia, Cirebon, Indonesia \\ 2,3 Department of Management, Universitas Catur Insan Cendekia, Cirebon, Indonesia
}

\section{JEL Classification: M48, G32}

Keywords:

Deceptive behavior, trust, intention to buy, purchase, e-commerce.

\section{"Corresponding Author: dewi.puspita@cic.acid \\ DOI: 10.20885/ica.vol3.iss 1.art5}

Copyright (C2021

This is an open access under CC-BY-SA LICENSE

\begin{abstract}
This study aims to analyze and obtain empirical evidence of deceptive behavior as a moderating variable of trust in purchasing through ecommerce purchase intentions. The data of this research were obtained from the results of collecting a questionnaire of 100 respondents who were consumers who had made transactions through e-commerce sites. Testing the hypothesis in this study using the measurement model (Outer Model) and structural models (Inner Model) with the application of Partial Least Square (PLS). The PLS program used is SmartPLS version 3.02.8. The results of this study indicate that trust has a positive effect on purchase intentions. However, with deceptive behavior as moderation, deceptive behavior weakens the relationship between trust in purchasing through E-Commerce and purchase intention as a mediating variable. Purchase intention is proven to be a mediating variable that mediates trust in mentally buying. The government should be more assertive in handling cases of e-commerce crime that are rife to create security and comfort for e-commerce site users.
\end{abstract}

\section{Introduction}

In the current era of globalization, technology and information are developing quite rapidly, especially the use of the internet. The internet is not only used to find information but has also been used as a means of communication so that many Indonesians use the internet. The internet is widely used by business people and producers as a marketing medium to market their products. Electronic commerce (e-commerce) is the use of computer networks to buy, sell, transfer, and exchange products, services, or information (Anwar \& Adidarma, 2016). The emergence of e-commerce today has made it easier for consumers to shop. People do not need to go to shopping centers such as markets, supermarkets, supermarkets, or malls. People only need to look for necessities through a computer connected to the internet. So that currently perceived usefulness and perceived ease of use affect satisfaction (Cho, 2016; Hossain et al., 2019; Kholid et al., 2018).

Trust is the basis for an online buying and selling transaction. A business transaction between two or more parties will occur when each of them trusts the other. Trust is a key factor in online buying and selling (Koufaris \& Hampton-Sosa, 2004). The trust that is formed will affect consumer purchase intentions in online stores. Purchase intention is the desire of consumers to buy certain goods. The development of trade through e-commerce, of course, creates new problems, namely the number of cases of fraud when shopping online.

The increasing number of online shopping sites has made many people abuse the convenience of these online shopping sites. Fraudulent behavior that often occurs in the community is that many goods are not sent by the seller of the goods, the goods do not match the picture, sometimes even not according to the quality that is informed on the online shop. In this case of fraud, of course, the consumer feels aggrieved, sometimes even consumer data can also be misused. Fraud cases often occur on online buying and selling sites, so that the trust factor is of 
great concern to online consumers. Perceived risk factors and trust have a strong influence on buying interest which leads to purchasing decisions that consumers will take (Kim \& Park, 2013). The existence of deceptive behavior that occurs in e-commerce transactions greatly affects consumer purchase intentions. Purchase intention is measured by asking about the possibility of buying products offered on online buying and selling sites. Purchase intention is a stage of the consumer's tendency to act before actually making a purchase (Martinez \& Kim, 2011). According to the Theory of Reasoned Action (TRA) or the theory of reasoned action developed by Ajzen and Fishbein (1980), it is explained that intention will influence a person's behavior in determining the decision to do or not do a behavior.

The research object and location of this study are also different from previous studies. Previous studies were only conducted in the city of Aceh with the e-commerce site Zalora.co.id (Meutia \& Meldi, 2017), students of the Faculty of Economics, Yogyakarta State University (Ariwibowo \& Nugroho, 2013), in the city of Semarang with an e-commerce site. Bukalapak.com (Yunita et al., 2017), and consumers who use GO-JEK online transportation services in the Semarang area (Maharama \& Kholis, 2018), Whereas in this study the objects used were all ecommerce customers in Indonesia who came from all walks of life such as housewives, workers, students, and other professions.

In the research of Yunita et al. (2017), purchase intention is not an intervening variable that mediates trust in online purchases on the Bukalapak.com e-commerce site. Purchase interest is proven to be able to play a role as an intervening variable, but the object of this research is consumers who use online transportation services, not consumers who use e-commerce sites (Maharama \& Kholis, 2018). A person's decision to make online purchase transactions is described in the Theory of Reasoned Action (TRA) (Ajzen \& Fishbein, 1980). Explained the parsimony of behavior and actions. This theory combines the attitude which in this study is represented by the variable of fraud risk, a subjective norm which in this study is represented by the variable of trust, an intention which in this study is represented by the purchase intention variable, and the behavior which in this study is represented by the purchase variable. This research is expected to provide benefits to provide knowledge on the extent to which fraud risk moderates trust in purchases through e-commerce with purchase intentions as a mediating variable and can be a reference material for researchers with similar problems. As a material for traders who use e-commerce sites in running their business to increase consumer confidence. For consumers, it can be a consideration in making purchasing decisions through e-commerce by being aware of the fraud risk that can later occur.

\section{Literature Review}

\section{Theory of Reasoned Action (TRA)}

Theory of Reasoned Action (TRA) is a theory developed by (Ajzen \& Fishbein, 1980), Theory of Reasoned Action (TRA) offers a persistent explanation of a behavior or action. This theory explains that intention (intention) will influence a person's behavior in determining the decision to do or not to do a behavior. The intention to do or not do certain behaviors is influenced by basic determinants, the first is related to attitudes towards behavior (attitude towards behavior) and the other is related to social influences, namely subjective norms (Ajzen \& Fishbein, 1980), TRA assumes a causal chain that connects behavioral beliefs and normative beliefs with behavioral and behavioral intentions, through attitudes and subjective norms (Ajzen \& Fishbein, 1980). The reason for using the theory of reasoned action in this study is because this theory provides a basis for analyzing the behavioral components in operational items. Right on target in predicting behavior can be directly observed and within one's control. Based on two main constructs as a determinant of intention (intention) for individuals to carry out certain behaviors, namely attitudes toward behavior and subjective norms (Ajzen \& Fishbein, 1980). 


\section{E-commerce}

E-commerce is a new form of the trading industry that is changing the face of the global economy. This factor is one of the main triggers for the shift in the trading industry which directly benefits because the existence of an e-commerce system is very useful in cutting costs and at the same time helping business people in establishing relationships with customers. In other words, e-commerce is a way in which sellers and buyers interact and make transactions through computer networks and online services (Bojang, et al., 2017). E-commerce is the activity of selling and buying goods or services via the internet. E-commerce can be done by anyone, without limitation of space and time (Ariwibowo \& Nugroho, 2013).

\section{Trust}

Trust is the belief of certain parties towards others in conducting transaction relationships based on a belief that e-commerce sites consist of ability, benevolence, and integrity (McKnight \& Chervany, 2001). So trust is defined as one of the social consequences because humans interact with other people. This consequence arises because interacting in buying and selling requires one important point before the buyer decides to buy from the seller, namely trust in the seller. In ecommerce transactions, trust is applied before the transaction and after the purchase transaction, which is the belief after this purchase transaction as a direct experience for the buyer whether on another occasion the buyer will decide to make a transaction with the same seller (Maharama \& Kholis, 2018). Trust is divided into two, namely offline trust, which appears between offline sellers and customers, and the second is online trust, which is between online sellers and customers (Koufaris \& Hampton-Sosa, 2004). In TRA, the subjective norm is a person's perception or view of social pressure (other people's beliefs) which will influence the intention to do or not do the behavior that is being considered (Ajzen \& Fishbein, 1980). This means that there are individual or group beliefs that agree or disagree in carrying out a behavior

$\mathbf{H}_{1}$ : Trust has a positive effect on purchases through e-commerce with purchase intention as a mediation

\section{Fraud Risk}

The fraud risk through e-commerce is an illegal transaction to gain profit for online sellers which of course will harm consumers financially and cause consumer fear and become a security threat for e-commerce consumers (Kim, Ferrin, and Rao 2008). Fraud has been regulated as a criminal offense under Article 378 of the Criminal Code. Online fraudulent behavior is the same as conventional fraud. The difference is only in the means of action, namely using electronic systems (computers, internet, telecommunications equipment) (Monica 2013). The rapid development of the use of internet services has resulted in other negative impacts, namely in the form of crimes and violations which later emerged the term cybercrime (Monica, 2013). So that in the current digital era, reliable investigative skills are needed in uncovering fraudulent practices (Sumartono et al., 2020). Attitude in the TRA developed by (Ajzen \& Fishbein, 1980) where the intention to do or not do certain behavior is influenced by basic determinants, the first is related to attitude towards behavior in this study represented by the fraud risk variable. Based on the description above, the following hypothesis is formulated:

$\mathbf{H}_{2}$ : Fraud risk moderates trust in purchase intentions through e-commerce

\section{Intention to Buy}

Purchase intention formation is a theory of reasoned action, this theory is taken from previous research on attitudes related to the relationship between behavior and Fishbein 1980). Purchasing interest is the psychological aspect that influences a person's behavior (Schiffman and Kanuk 2007). The purchase decision is preceded by the intention in the mind of the buyer to make an online 
purchase transaction that was previously trusted (Yunita et al. 2016). High consumer buying interest will encourage consumers to make purchase transactions online. It is buying interest that will deter consumers from making purchases online. in TRA developed by (Ajzen \& Fishbein, 1980) that intention will influence a person's behavior in determining the decision to do or not to do the behavior. in this study, the intention is represented by the intention to buy variable

\section{Purchase}

The purchase decision is a stage in the process where consumers purchase so that the purchase decision is part of consumer behavior when deciding to buy. Complex psychological behavior, which appears in the form of unique behaviors in individuals who are directly involved in acquiring and using products, and determining the product decision-making process, including repurchasing (Zulfa \& Hidayati, 2018). TRA developed by (Ajzen \& Fishbein, 1980) said that intention that affects behavior is influenced by basic determinants, the first is related to attitudes towards behavior (attitude towards behavior) and the other is related to social influences, namely subjective norms.

\section{Research Methods}

The method used in this research is a quantitative approach, using a survey method through a questionnaire. The survey was conducted on respondents who had shopped via e-commerce sites in the last 6 months at least. The data used in this study are primary. The primary data in this study is in the form of questionnaire results obtained from respondents who use e-commerce sites in major cities in Indonesia. The population used in this study are consumers who have bought goods/products through e-commerce websites in Indonesia. The sample of this research is consumers of all professions who have purchased goods through e-commerce websites in major cities in Indonesia, including the islands of Sumatra (Palembang City), Java, and Bali (Jakarta, Bandung, Semarang, Yogyakarta, Surabaya, Denpasar), Kalimantan Island (Pontianak City), Sulawesi Island (Makassar City and Kendari City). In this study, the sample used was 100 respondents of the total respondents divided by ten cities, each city consists of about seventeen to twenty respondents. The data research method in this study is purposive sampling.

\section{Technical Analysis Data}

This study conducted data analysis using Smart PLS version 3.2.8 software (Ghozali \& Latan, 2015). The structural model test (inner model) can be seen using the R-square to assess how much influence certain independent variables have on the dependent variable, and the path coefficient or p-value of each path t.

Table 1. Testing Phase of the Measurement Model

\begin{tabular}{|c|c|c|c|}
\hline Stages & Type of Measurement & Terms & Source \\
\hline Convergent & AVE Value & $>0.5$ & (Ghozali \& Latan, 2015) \\
\hline Validity Test & The loading value of each item & $>0.05$ & (Ghozali \& Latan, 2015). \\
\hline $\begin{array}{l}\text { Discriminant } \\
\text { Validity Test }\end{array}$ & The square root value of $\mathrm{AVE}$ & $\begin{array}{l}\text { The value of the square } \\
\text { root of AVE is greater } \\
\text { than the correlation value } \\
\text { between constructs }\end{array}$ & (Ghozali \& Latan, 2015). \\
\hline Reliability Test & Composite Reliability value & $>0.7$ & (Ghozali \& Latan, 2015). \\
\hline
\end{tabular}

\section{Results and Discussion}

Respondents in this study are consumers who have purchased products/goods through ecommerce websites in Indonesia. There are 19 questions to be tested in the questionnaire in this 
study which must be answered by 100 respondents. The majority of respondents in this study were women with a percentage rate of $73.8 \%$. As for the age group 25-35 years with a percentage rate of $34.2 \%$, based on the work of employees with a percentage rate of $40.6 \%$. Meanwhile, based on the education level of the majority of undergraduates with a percentage level of $55.1 \%$, the average income that often makes online purchases is 1-5 million with a percentage level of $62.6 \%$.

\section{Evaluation of Measurement Model (Outer Model) \\ Convergent Validity Test}

The indicator is considered valid if the AVE value is above 0.5 or shows that all outer loading dimensions of the variable have a loading value of $>0.5$ (Ghozali \& Latan, 2015). In this study, each question item had a value above 0.5 and also the AVE value for each variable had a value above 0.5. so it can be concluded that all indicators in the variables in this study can be declared valid.

\section{Discriminant Validity Test}

The discriminant validity test can be accepted if the square root value of AVE is greater than the correlation value between constructs (Ghozali \& Latan, 2015). Another way to fulfill the discriminant validity test is to look at the cross-loading value for each instrument which must be more than 0.5 (Ghozali \& Latan, 2015). In this study, the correlation value for each variable with the variable itself has a greater value than the correlation with other variables. Thus, all variables in this study were declared valid and had met the discriminant validity test.

\section{Reliability Test}

To test the reliability of a construct, it can be seen from the composite reliability value. A construct is declared reliable if it has a composite reliability value above 0.7 (Ghozali \& Latan, 2015). From Table 2, it can be concluded that all the variables used in this study are reliable because all variables have a composite reliability value $>0.7$.

Table 2. Value of Composite Reliability

\begin{tabular}{lcc}
\hline Variabel & Composite Reliability & Explanation \\
\hline Trust & 0.938 & Reliable \\
Moderating Effect 1 & 1.000 & Reliable \\
Intention to Buy & 0.918 & Reliable \\
Purchase & 0.884 & Reliable \\
Fraud risk & 0.872 & Reliable \\
\hline
\end{tabular}

\section{Evaluation of the Structural Model (Inner Model)}

After the outer model requirements are accepted, the next step is to evaluate the structural model (inner model). The structural model can be seen through the R-square value which aims to assess how much influence the independent variable has on the dependent variable and path coefficients (Ghozali \& Latan, 2015).

Table 3. R-Square Value

\begin{tabular}{ll}
\hline Variable & R-Square \\
\hline Intention to Buy & 0.353 \\
Purchase & 0.619 \\
\hline
\end{tabular}

The last analysis is hypothesis testing through the bootstrapping procedure. A relationship can be declared significant and accepted if the p-value is more than 0.5. 
Table 4. Path Coefficients and T-Statistics

\begin{tabular}{llcc}
\hline \multicolumn{1}{c}{ Construct } & Original Sample $(\mathrm{O})$ & $p$-value & Explanation \\
\hline Trust $\rightarrow$ Intention to Buy & $(+) 0.428$ & 0.000 & Supported \\
Moderating Effect $1 \rightarrow$ Intention to Buy & $(-) 0.136$ & 0.014 & Supported \\
Intention to Buy $\rightarrow$ Purchase & $(+) 0.789$ & 0.000 & Supported \\
Fraud Risk $\rightarrow$ Niat membeli & $(-) 0.302$ & 0.005 & Supported \\
\hline
\end{tabular}

Table 5. Path Coefficients and T-Statistics

\begin{tabular}{llll}
\hline Construct & Original Sample $(\mathrm{O})$ & $p$-value & Explanation \\
\hline Trust $\rightarrow$ Intention to Buy $\rightarrow$ Purchase & $(+) 0.337$ & 0.000 & Supported \\
Moderating Effect $1 \rightarrow$ Intention to Buy $\rightarrow$ Purchase & $(-) 0.107$ & 0.015 & Supported \\
Fraud risk $\rightarrow$ Intention to Buy $\rightarrow$ Purchase & $(-) 0.238$ & 0.004 & Supported \\
\hline
\end{tabular}

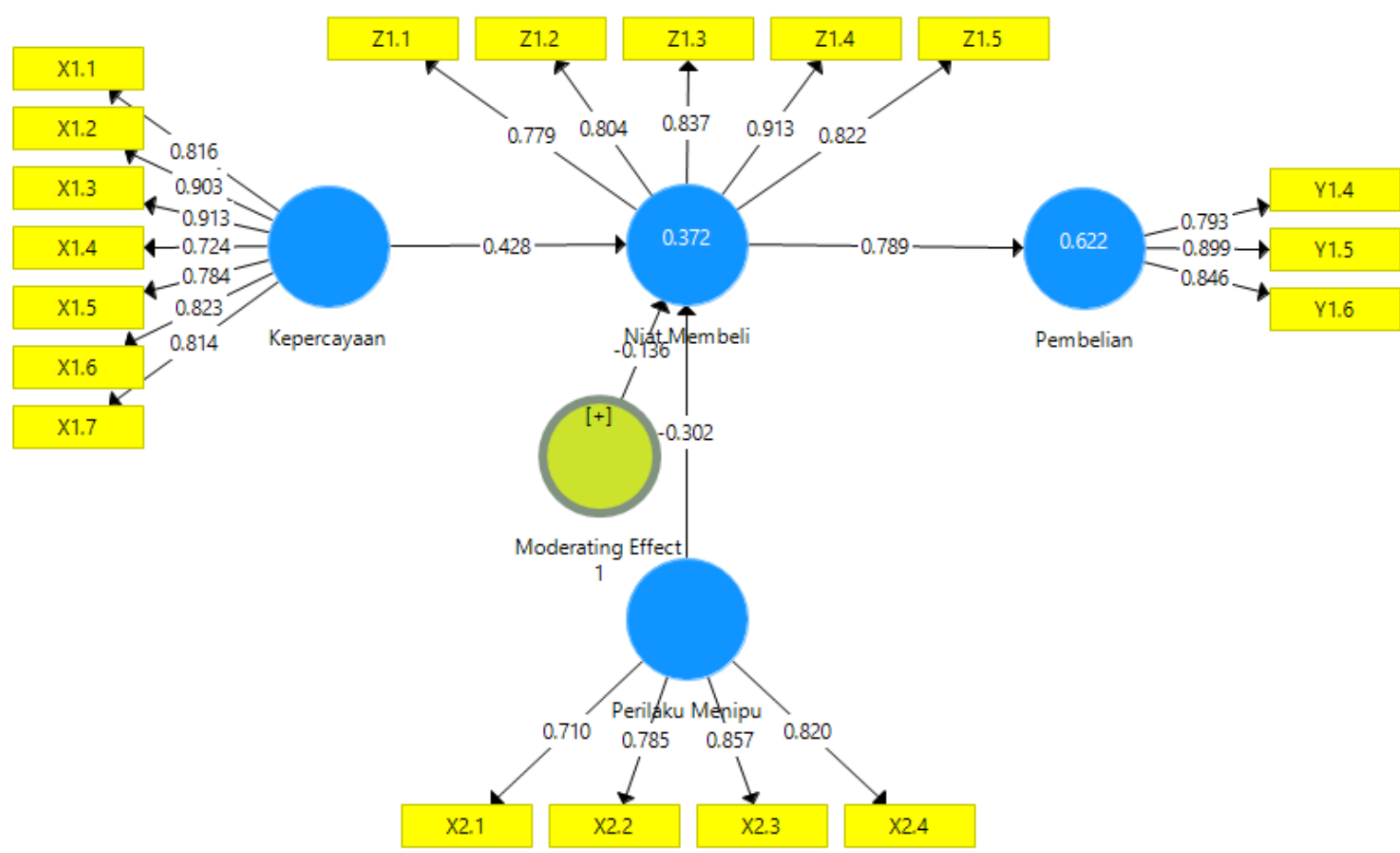

Figure 1. Research Model

\section{Trust has a positive effect on purchases through e-commerce with purchase intention as a mediation}

Trust is an important foundation in doing business. In various transactions between sellers and buyers with the aim that customer satisfaction is realized as expected (Koufaris \& Hampton-Sosa, 2004). The result of the trust path coefficient on the purchase intention variable through the purchase intention, the value of the parameter coefficient is 0.337 so that there is an effect of trust on purchase intentions on e-commerce sites. In this study, it was obtained a p-value of 0,000 or $<0.05$, which means that there is a significant effect. With a sense of trust, consumers feel that transactions using e-commerce sites are quite safe and as expected. According to the TRA developed by Ajen, who said that the subject norm in this study, the variable of service has an effect on behavior in this study. Purchasing through intention in this study is purchase intention. purchase intention is proven to be a mediator of the influence of trust on purchases on e-commerce sites. so that the first hypothesis of this study is supported. 


\section{The second hypothesis fraud risk moderates the effect of trust on purchase intention}

Behavior error is taking one of the considerations into consideration for online consumers (Anwar \& Adidarma, 2016). Results of the Coordination of Behavior Coordination Analysis Value Coefficient Parameter Value Coefficient -0.107 so that there is an effect of deceptive behavior on e-commerce sites. The more deceptive behavior in an e-commerce transaction, the lower the purchase intention. In this study, it was obtained a p-value of 0,000 or $<0.05$, which means that there is a significant effect. Even though a person's trust has the intention of buying, the fraud risk can weaken the influence of trust on a person's intention to buy on an e-commerce site (Puspitarini, 2020). This study supports the theory developed by Ajzen and Fishbein (1980) that a person's behavior will influence a decision that the attitude in this study is represented by the variable of fraud risk on intention, in this case, the intention to buy in e-commerce. So that the second hypothesis of this study is supported.

\section{Conclusion}

This study aims to determine deceptive behavior as a moderating variable of trust in purchases through e-commerce purchase intentions. As we all know, the issue of fraud has recently occurred in online buying and selling media. Based on the results of the discussion in the previous chapter, the conclusion is that there is an influence of trust on purchases through purchase intention on ecommerce sites, and then the results of this study also show that deceptive behavior moderates the effect of trust on purchase intentions.

The government must act decisively in handling cases of fraud in e-commerce transactions and impose sanctions by applicable laws. Sellers on e-commerce sites must increase security so that fraudulent behavior such as deceptive behavior that harms consumers financially or misuses the identity of buyers does not occur in purchase transactions through e-commerce sites. Sellers on ecommerce sites should continue to maintain good relationships and make consumers feel comfortable and then a high sense of trust will arise, therefore trust is the main capital of consumers when deciding to make transactions on e-commerce sites. The higher the consumer's trust, the stronger the purchase intention through e-commerce sites. Consumers who have become victims of crimes in e-commerce transactions are advised to report to the authorities if their rights have been violated by business actors.

The suggestions for further study are that researchers can develop this research by adding variables that have not been used in this study and using the development of TRA theory, namely TPB so that there are control variables that affect purchases in transactions on e-trading sites. The sample could be more and from all capital cities in Indonesia.

\section{References}

Ajzen, \& Fishbein, M. (1980). Understanding Attitudes And Predicting Sosial Behavior. Englewood Cliffs. Nj: Prentice-Hall.

Anwar, R., \& Adidarma, W. (2016). Penngaruh Kepercayaan Dan Risiko Pada Minat Beli Belanja Online. Jurnal Manajemen Dan Bisnis Sriwijaya, 14(2), 155-168.

Ariwibowo, D. P. J., \& Nugroho, M. A. (2013). Pengaruh trust dan perceived of risk terhadap niat untuk bertransaksi menggunakan e-commerce. Jurnal Nominal, 2(1), 11-35.

Bojang, I., Medvedev, M. A., Spasov, K. B., \& Matvevnina, A. I. (2017). Determinants of trust in B2C e-commerce and their relationship with consumer online trust. AIP Conference Proceedings 1910, 020001. https://doi.org/10.1063/1.5013938

Cho, J. (2016). The impact of post-adoption beliefs on the continued use of health apps. International Journal of Medical Informatics, 87, 75-83. 
Ghozali, I., \& Latan, H. (2015). Partial Least Squares $\square$ : Konsep, Teknik dan Aplikasi Menggunakan Program SmartPLS 3.0 (2nd ed.). Badan Penerbit Universitas Dipenogoro Semarang.

Hossain, S. F. A., Nurunnabi, M., Hussain, K., \& Saha, S. K. (2019). Effects of variety-seeking intention by mobile phone usage on university students' academic performance. Cogent Education, 6(1), 1-18.

Kholid, M. N., Urumsah, D., \& Hamdani, R. (2018). Expectation confirmation model in the transportation order applications: gender differences. Proceedings of the 31st International Business Information Management Association Conference.

Kim, S., \& Park, H. (2013). Effects of various characteristics of social commerce (s-commerce) on consumers' trust and trust performance. International Journal of Information Management, 33(2), 318-332. https://doi.org/10.1016/j.ijinfomgt.2012.11.006

Koufaris, M., \& Hampton-Sosa, W. (2004). The development of initial trust in an online company by new customers. Information and Management, 41(3), 377-397. https://doi.org/10.1016/j.im.2003.08.004

Maharama, A. R., \& Kholis, N. (2018). Pengaruh kepercayaan, kemudahan, dan presepsi risiko terhadap keputusan pembelian jasa gojek di kota Semarang yang dimediasi minat beli sebagai variabel intervening. Jurnal Ekonomi Dan Bisnis, 19(2), 203-213.

Martinez, B., \& Kim, S. (2011). Predicting purchase intention for private sale sites. Journal of Fashion Marketing and Management, 16(3), 342-365. https://doi.org/10.1108/03090560410539302

McKnight, D. H., \& Chervany, N. L. (2001). What trust means in e-commerce customer relationships: An interdisciplinary conceptual typology. International Journal of Electronic Commerce, 6(2), 35-59. https://doi.org/10.1080/10864415.2001.11044235

Meutia, S. D., \& Meldi, T. K. (2017). Pengaruh resepsi risiko, persepsi manfaat dan kepercayaan terhadap niat pembelian konsumen di portal e-commerce. Jurnal Iilmiah Mahasiswa Ekonomi Manajemen, 2(1), 202-223.

Puspitarini, D. A. (2020). Pengaruh kepercayaan terhadap keputusan transakasi menggunakan ecommerce dengan niat transaksi sebagai variabel mediasi. Jurnal Ekonomi, Bisnis, Dan Industri, 2(2), 25-32.

Sumartono, Urumsah, D., \& Hamdani, R. (2020). Skills of the forensic accountants in revealing fraud in public sector: The Case of Indonesia. Journal of Accounting and Investment, 21(1), 180-194. https://doi.org/10.18196/jai.2101144

Yunita, R. D., Yulianeu, Haryono, A. T., \& Gagah, E. (2017). Pengaruh kepercayaan konsumen, kemudahan dan kualitas informasi terhadap keputusan pembelian secara online dengan minat beli sebagai variabel intervening (Studi pada pengguna situs jual beli Bukalapak.com). Journal of Management, 3(3), 1-7. 